\title{
FINE NEEDLE ASPIRATION CYTOLOGY OF MALE BREAST LESIONS- A DESCRIPTIVE STUDY OVER A PERIOD OF FIVE YEARS
}

\author{
Garima1, Tanu Agrawal ${ }^{2}$
}

1 Junior Resident, Department of Pathology, Shri Ram Murti Smarak Institute of Medical Sciences, Bareilly. 2Professor, Department of Pathology, Shri Ram Murti Smarak Institute of Medical Sciences, Bareilly.

\author{
ABSTRACT

\section{BACKGROUND} \\ Fine needle aspiration cytology is known to have a well-established role in the diagnosis and management of palpable breast \\ lumps. Breast carcinoma is the second most common cause of death in female patients, male breast carcinoma is rare, accounting \\ for less than $1 \%$ of all breast cancers and all cancers in men. Male breast masses are rarely aspirated and hence there is limited \\ cytopathological experience. \\ The aim of our study is to determine the efficacy of FNAC in the diagnosis of male breast lesions.
}

\section{MATERIALS AND METHODS}

A five-year descriptive study was conducted from July 2011 to June 2016 and data on male breast FNAC were retrieved from the cytopathology records. Cytohistological correlation was done with data from histopathology records.

\section{RESULTS}

68 male patients underwent breast FNAC. The FNAC diagnosis was categorised as benign (85.3\%), malignant (7.4\%), suspicious for malignancy (2.9\%) and inadequate or unsatisfactory (4.4\%). Gynaecomastia was the commonest benign lesion seen in 53 $(91.3 \%)$ out of 58 cases. Histopathology was available in 19 (27.9\%) out of 68 cases. FNAC had a sensitivity, specificity and diagnostic accuracy of $100 \%$ for male breast lesions in the present study.

\section{CONCLUSION}

The present study shows that FNAC is a very reliable, sensitive and specific diagnostic tool for the early diagnosis of male breast lesions.

\section{KEYWORDS}

FNAC, Breast Carcinoma, Gynaecomastia, Male Breast.

HOW TO CITE THIS ARTICLE: Garima, Agrawal T. Fine needle aspiration cytology of male breast lesions- A descriptive study over a period of five years. J. Evolution Med. Dent. Sci. 2017;6(54):4067-4071, DOI: 10.14260/Jemds/2017/879

\section{BACKGROUND}

Gynaecomastia is the commonest cause of benign masses in the male breast. Carcinoma of the male breast is a rare disease representing $1 \%$ of all breast cancers and less than $1 \%$ of all cancers in men. ${ }^{1-3}$

FNAC is a very quick, accurate and patient-friendly method in the workup of swellings from a variety of body sites and also has a well-established role in the management of palpable breast lumps.4,5 This procedure has a high diagnostic accuracy when performed and interpreted by experienced cytopathologist and can be used for diagnostic workup of lesions of male breast.

In this study, we will describe our experience with FNAC of breast lesions occurring in men over a period of 5 years at a tertiary care hospital.

Financial or Other, Competing Interest: None.

Submission 22-05-2017, Peer Review 22-06-2017,

Acceptance 29-06-2017, Published 06-07-2017.

Corresponding Author:

Dr. Garima

Department of Pathology

Shri Ram Murti Smarak Institute of Medical Sciences,

Nainital Road, Bhojipura,

Bareilly-243202,

Uttar Pradesh, India.

E-mail: garimaprasad@rocketmail.com

DOI: $10.14260 /$ jemds $/ 2017 / 879$

\section{MATERIALS AND METHODS}

Previous medical records of the patients who underwent FNAC of breast lumps at our hospital from July 2011 to June 2016 were retrieved and the reports on the male breast aspirates were reviewed.

All FNAs were carried out in the outpatient department using a suitable needle and syringe by an experienced cytopathologist. Smears were prepared by air drying and were stained by the May-Grunwald-Giemsa method. Wetfixed smears were also prepared by fixation in 95\% ethyl alcohol and subsequent staining with Pap stain.

These stained smears were examined by an experienced cytopathologist of our institute and classified into four major categories including benign, malignant, suspicious of malignancy and unsatisfactory aspirate.

Histopathological diagnosis wherever available were reviewed and the cytological diagnosis and histologic findings were correlated with each other and a descriptive study was carried out. Statistical analysis was then carried out by calculating the sensitivity, specificity and diagnostic accuracy of the aspirates.

\section{RESULTS}

Over a five-year period, 68 male patients with palpable breast lumps underwent Fine needle aspiration (FNA) at our hospital. Of these, 64 patients had a unilateral lump (left breast 29 and right breast 35) and 4 patients had a bilateral lump. 
The age ranged from 11 to 77 years with a median age of 44 years. These aspirates were each categorised into the following groups: benign 58 (85.3\%), malignant 5 (7.4\%), suspicious for malignancy 2 (2.9\%) and nondiagnostic/unsatisfactory $3(4.4 \%)$. The specificity, sensitivity and diagnostic accuracy was $100 \%$ in our study.

Gynaecomastia was the commonest diagnostic lesion encountered in our study. Smears from gynaecomastia revealed variable amount of cellular material, ranging from moderate cellularity to extreme hyper cellularity with large number of crowded tissue fragments.

However, more commonly a moderately cellular smear pattern was noted. Smears showed large, tightly cohesive fragments, and flat monolayered sheets of epithelial cells. Scattered bipolar and oval myoepithelial nuclei and stromal fragments were noted in the background of the smears. Only 19 cases were confirmed histologically.

\begin{tabular}{|c|c|}
\hline Cytologic Diagnosis & Number of Cases \\
\hline Benign (85.3\%) & $55(94.8 \%)$ \\
Gynaecomastia & $2(3.4 \%)$ \\
Lipoma & $1(1.7 \%)$ \\
Abscess & 05 \\
\hline Malignant (7.4\%) \\
Infiltrating ductal carcinoma & 02 \\
\hline $\begin{array}{c}\text { Inconclusive/suspicious for } \\
\text { malignancy (2.9\%) }\end{array}$ & 03 \\
\hline Unsatisfactory (4.4\%) & Cytological Diagnosis \\
\hline Table 1. Distribution of Cases on the Basis of their \\
\hline
\end{tabular}

\begin{tabular}{|c|c|c|}
\hline Cytologic Diagnosis & $\begin{array}{c}\text { Histopathological } \\
\text { Diagnosis }\end{array}$ & Number \\
\hline Gynaecomastia & Gynaecomastia & 13 \\
\hline Lipoma & Lipoma & 02 \\
\hline Ductal carcinoma & $\begin{array}{c}\text { Infiltrating ductal } \\
\text { carcinoma (NOS) }\end{array}$ & 02 \\
\hline $\begin{array}{c}\text { Inconclusive/suspicious } \\
\text { of malignancy }\end{array}$ & $\begin{array}{c}\text { Infiltrating ductal } \\
\text { carcinoma (NOS) }\end{array}$ & 02 \\
\hline
\end{tabular}

Table 2. Cytohistological Correlation of the 19 Cases in which Histopathology was Available

\begin{tabular}{|c|c|c|}
\hline \multirow[b]{2}{*}{ Cytology } & \multicolumn{2}{|c|}{ Histopathology } \\
\hline & $\begin{array}{c}\text { Positive } \\
\text { (malignant) }\end{array}$ & $\begin{array}{l}\text { Negative } \\
\text { (benign) }\end{array}$ \\
\hline Benign (15) & $\begin{array}{c}0=\text { false } \\
\text { negative }(0 \%)\end{array}$ & $\begin{array}{c}15=\text { true } \\
\text { negative }(100 \%)\end{array}$ \\
\hline Malignant (02) & $\begin{array}{c}2=\text { true } \\
\text { positive } \\
(100 \%)\end{array}$ & $\begin{array}{c}0=\text { false positive } \\
(0 \%)\end{array}$ \\
\hline $\begin{array}{l}\text { Inconclusive/suspicious of } \\
\text { malignancy (02) }\end{array}$ & $2(100 \%)$ & $0(0 \%)$ \\
\hline Total (19) & $4(21.05 \%)$ & $15(78.94 \%)$ \\
\hline
\end{tabular}

Sensitivity $=\frac{\mathrm{TP}}{\mathrm{TP}+\mathrm{FN}} \mathrm{X} 100=\frac{2}{2+0} \mathrm{X} 100 \%=100 \%$
Specificity $=\frac{\mathrm{TN}}{\mathrm{TN}+\mathrm{FP}} \mathrm{X} 100=\frac{15}{15+0} \mathrm{X} 100 \%=100 \%$
Positive predictive value $=\frac{\mathrm{TP}}{\mathrm{TP}+\mathrm{FP}} \mathrm{X} 100=\frac{2}{2+0} \mathrm{X} 100 \%=100 \%$
Negative predictive value $=\frac{\mathrm{TN}}{\mathrm{TN}+\mathrm{FN}} \mathrm{X} 100=\frac{15}{15+0} \mathrm{X} 100 \%=100 \%$
Accuracy $=\frac{\mathrm{TP}+\mathrm{TN}}{\mathrm{TP}+\mathrm{FP}+\mathrm{TN}+\mathrm{FN}} \mathrm{X} 100 \%=100 \%$

\begin{tabular}{|c|c|c|c|c|c|c|c|}
\hline Result & $\begin{array}{c}\text { Westend } \\
\text { et al }\end{array}$ & $\begin{array}{c}\text { MacIntosh } \\
\text { et al }\end{array}$ & $\begin{array}{c}\text { Wauters } \\
\text { et al }\end{array}$ & $\begin{array}{c}\text { Kirana Pailoor } \\
\text { et al }\end{array}$ & $\begin{array}{c}\text { Byna Syam Sundara } \\
\text { Rao et al }\end{array}$ & $\begin{array}{c}\text { Ganguly S } \\
\text { et al }\end{array}$ & $\begin{array}{c}\text { Present } \\
\text { Study }\end{array}$ \\
\hline Year & 2002 & 2008 & 2009 & 2014 & 2015 & 2015 & 2017 \\
\hline Total no. of male FNAC & 153 & 138 & 147 & 40 & 15 & 38 & 68 \\
\hline $\begin{array}{c}\text { Total no. of available } \\
\text { biopsy }\end{array}$ & $72(47 \%)$ & $83(17 \%)$ & $25(58 \%)$ & $8(20 \%)$ & $10(66.6 \%)$ & $19(50 \%)$ & $19(27.9 \%)$ \\
\hline $\begin{array}{c}\text { Total no. of malignant } \\
\text { cases }\end{array}$ & $15(9.8 \%)$ & $11(7.9 \%)$ & $15(10.2 \%)$ & $1(4.16 \%)$ & $3(1.2 \%)$ & $4(10.5 \%)$ & $5(7.4 \%)$ \\
\hline $\begin{array}{c}\text { Total no. of } \\
\text { unsatisfactory cases }\end{array}$ & $18(11.7 \%)$ & $46(33.3 \%)$ & $45(30.6 \%)$ & 0 & 0 & $1(2.6 \%)$ & $3(4.4 \%)$ \\
\hline Sensitivity & $100 \%$ & $95.5 \%$ & $100 \%$ & $100 \%$ & $100 \%$ & $100 \%$ & $100 \%$ \\
\hline Specificity & $89 \%$ & $100 \%$ & $90.2 \%$ & $100 \%$ & $100 \%$ & $100 \%$ & $100 \%$ \\
\hline \multicolumn{7}{|c|}{ Table 4. Results of the Present Study in Comparison with Other Studies } \\
\hline
\end{tabular}

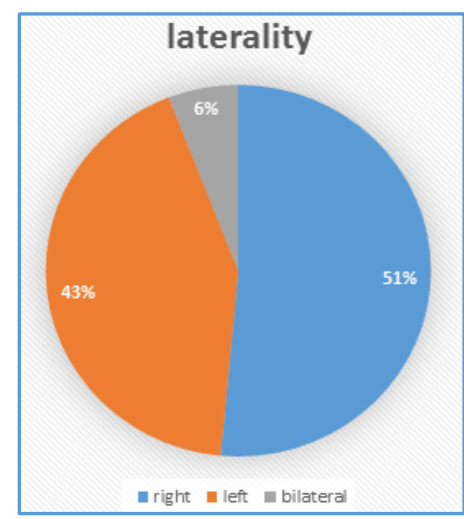

Figure 1. Laterality of the Breast Lesions

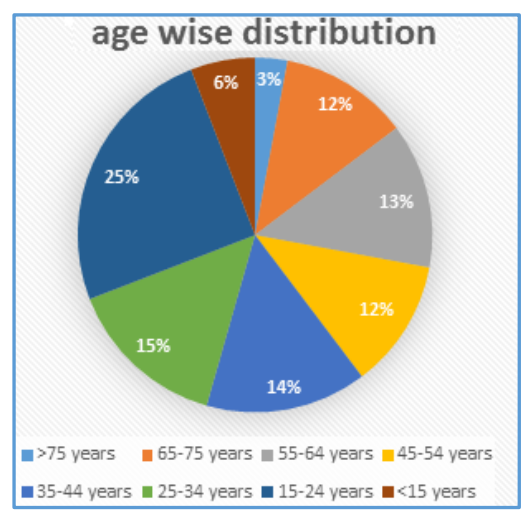

Figure 2. Age Distribution of the Cases 


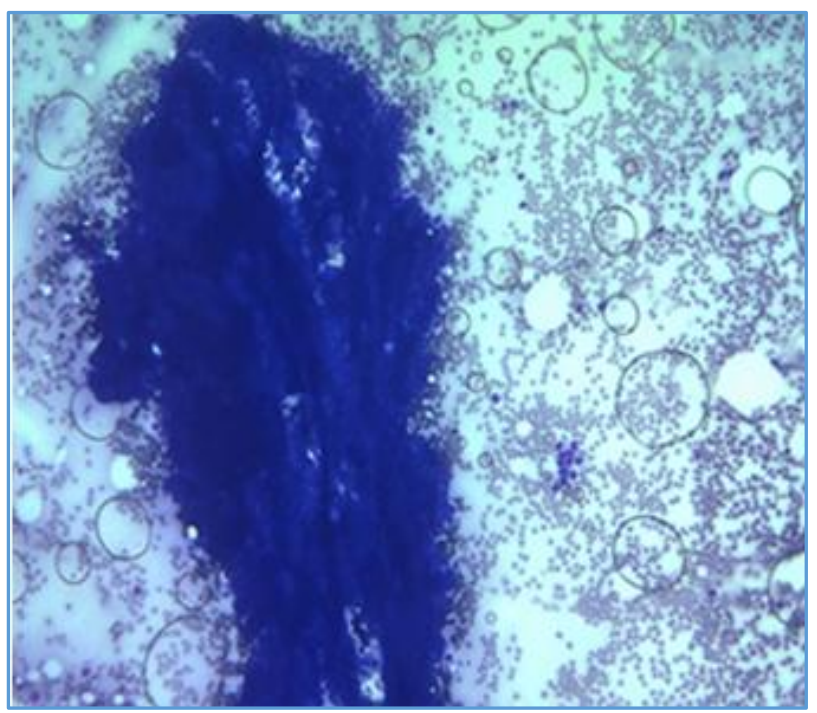

Figure 3. FNAC of Gynaecomastia showing Cohesive Fragment of Uniform Ductal Epithelial Cells (MGG 100X)

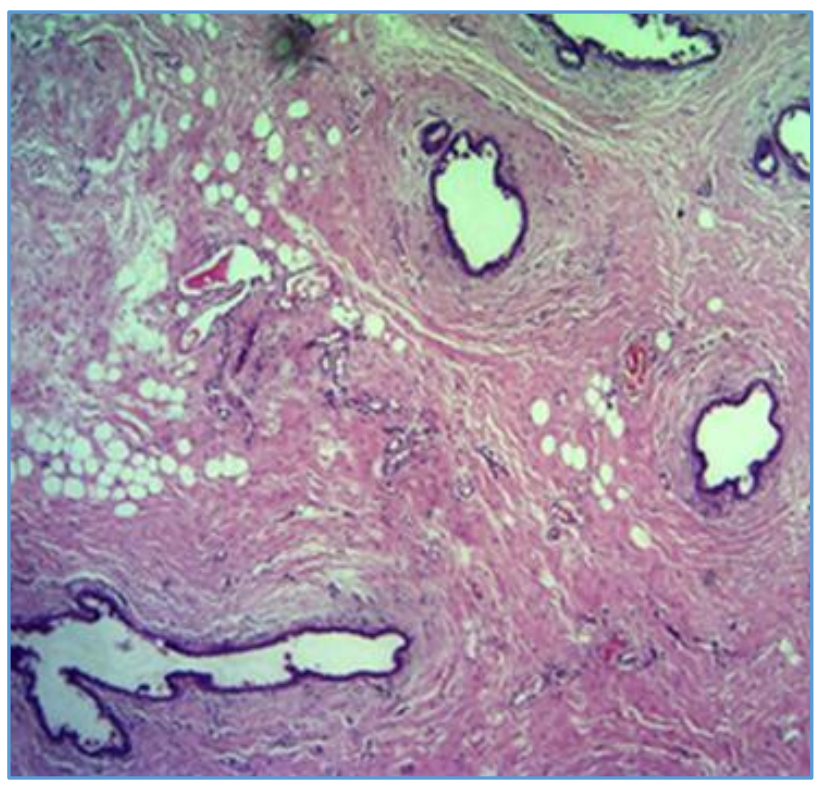

Figure 4. Photomicrograph of H\&E Stained Section of Gynaecomastia (100X)

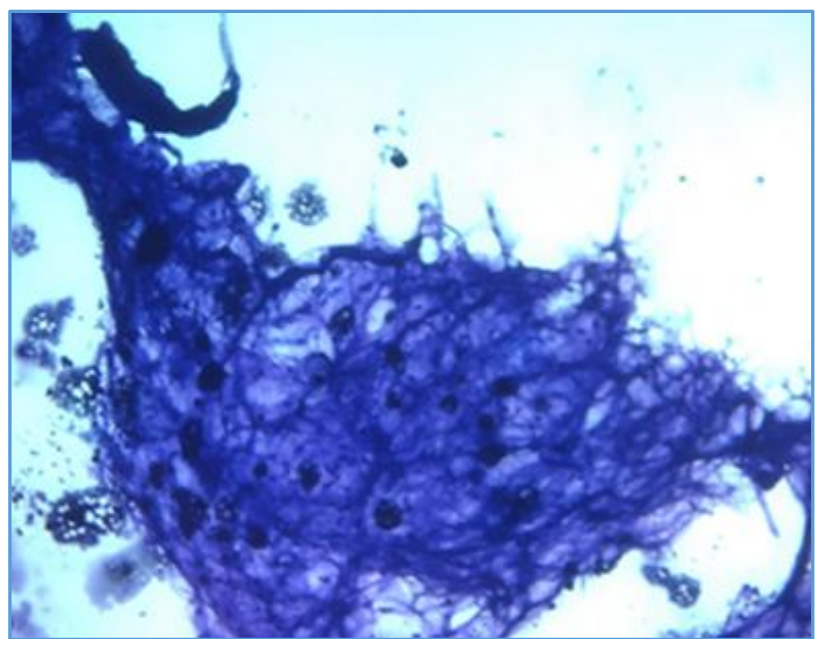

Figure 5. FNAC of Lipoma showing Fragment of Mature Adipose Tissue (MGG 100X)

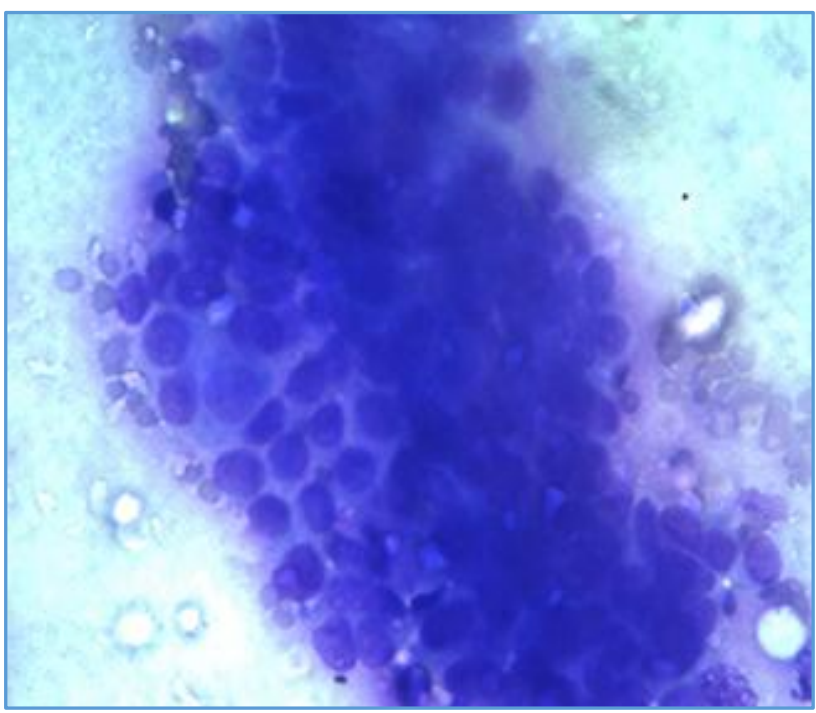

Figure 6. FNAC of Ductal Carcinoma showing Loosely Cohesive Cluster of Tumour Cells with Pleomorphic Hyperchromatic Nuclei (MGG 400X)

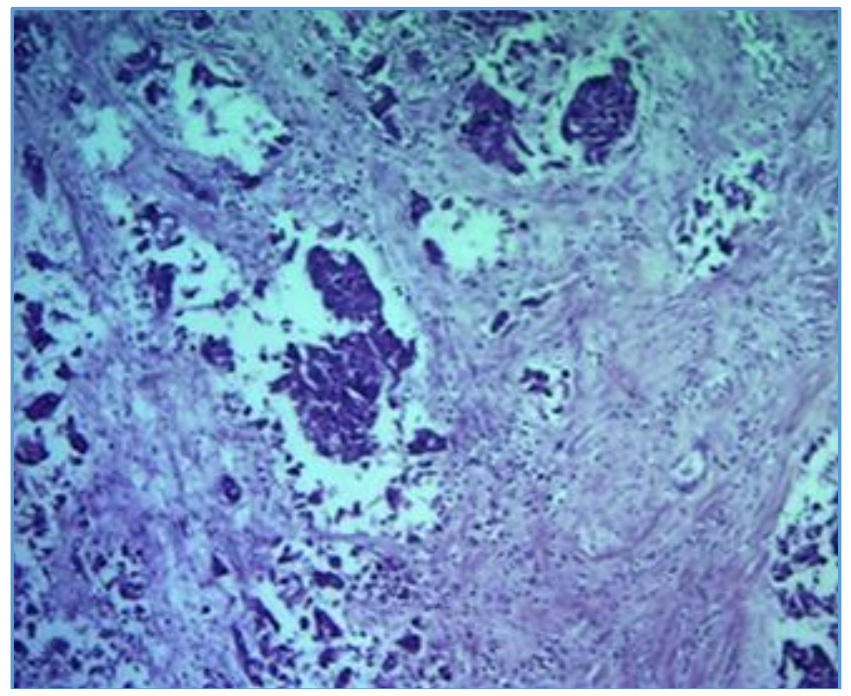

Figure 7. Microphotograph of H\&E Stained Section of Infiltrating Ductal Carcinoma (100 X)

\section{DISCUSSION}

Breast masses in males comprise less than $2 \%$ of the total cases in many FNAC studies of breast lumps. FNAC of male breast lesions is a diagnostically useful procedure.

It is cost effective with minimal discomfort to the patient and can be performed on OPD basis. Report may be available on the same day, minimising anxiety of the patient.

Carcinoma in male breast is very rare as compared to the female breast. ${ }^{6-7}$ The present study is undertaken to analyse the cytological spectrum of the male breast lesions.

In this study, FNAC was useful in separating malignant breast lumps from the common benign lumps like gynaecomastia. Gynaecomastia is the most common benign lesion encountered in this study.

The total number of male patients who underwent FNAC for the assessment of a breast lump is 68 over a 5 -year period. In our study, 55 out of 68 cases (80.9\%) were of gynaecomastia and was observed more on the right side, this was in contrast to the studies conducted by Das et $\mathrm{al}^{8}$ and Martin-Bates et $\mathrm{al}^{9}$ who observed it more in the left breast. 
Kirana Pailoor et al ${ }^{10}$ found $75 \%$ cases of gynaecomastia in a study of 40 cases of FNAC of male breast lesions, Jagannath et $\mathrm{al}^{11}$ found $91 \%$ cases of gynaecomastia in a study of 112 cases of FNAC of male breast lesions, which was almost similar to the result found in our study.

Age at presentation was variable with peak age in the fourth decade in the present study. Gynaecomastia was more common in patients less than 20 years of age. This was similar to findings in a study of Manas Kotepuia et al (2014). Russin et al $^{12}$ observed bimodal peak in the third and seventh decades.

Gynaecomastia is defined as the enlargement of the male breast due to proliferation of both stromal and glandular elements and is the commonest cause of masses in the male breast. 13

Gynaecomastia is the result of different factors that induce a benign proliferation of the duct epithelium and also increased periductal deposition of collagen. ${ }^{14}$ These variable causes share a background of comparative increase in oestrogenic activity and decrease in androgenic activity or both. ${ }^{15}$ A study by Ersek et al showed that in 33\% of pubertal cases, the condition subsided on its own within 1 year, and in $93 \%$ of cases, the condition subsided in 3 years. ${ }^{16}$

As our findings show, fine needle aspirates of gynaecomastia can have variable cellularity ranging from virtually acellular to richly cellular smears. ${ }^{10}$ Exact diagnosis of gynaecomastia requires the presence of cohesive epithelial cell sheets and bare nuclei in the background.

The male breast carcinoma is distinguished on cytology from gynaecomastia on the basis of high cellularity, discohesive cell groups with nuclear piling and anisonucleosis. ${ }^{10}$ All these features were observed in almost all cases of carcinoma of male breast. Absence of bipolar bare nuclei is an important clue.

In our study, $7.4 \%$ cases were infiltrating duct carcinoma which is similar to Wauters et al $(10.2 \%)^{17}$ and Westend et al $(9.8 \%){ }^{18}$ FNA smears were hypercellular with tumour cells in discohesive sheets and scattered singly.

The cells had pleomorphic vesicular nuclei with prominent nucleoli and had abundant eosinophilic cytoplasm. Biopsy was available in $27.9 \%$ cases (19 out of 68 ) as compared to that of Wauters et al (58\%) ${ }^{17}$ and Westend et al $(47 \%)^{18}$ and that of MacIntosh et al (17\%). ${ }^{14}$ Biopsy rate is less in case of benign lesions.

Cytological diagnosis and histopathological diagnosis of benign and malignant cases were consistent in $100 \%$ cases. Among lesions which were diagnosed as suspicious for malignancy on cytology, one case was found to be malignant (Infiltrating Ductal Carcinoma, NOS) on histopathology and one case was found benign (Gynaecomastia) on histopathological sections. Thus, in our study, cytological findings were consistent with histopathology in 19 cases out of 68 cases.

This study had $100 \%$ sensitivity similar to that of Westend et $\mathrm{al}^{18}$ and Wauters et $\mathrm{al}^{18}$ and $100 \%$ specificity similar to the studies by Siddiqui et $\mathrm{al}^{19}$ and MacIntosh et al. ${ }^{14}$

\section{CONCLUSION}

FNAC is a safe, easy, reliable, rapid, sensitive, specific, economical and highly accurate method for diagnosis of breast lump preoperatively.
Using FNAC as an initial investigation will greatly reduce the number of unnecessary biopsies and frozen sections for histopathologic evaluation, also preventing unnecessary anxiety, especially in case of gynaecomastia. Therefore, on the basis of this study, we strongly recommend FNAC as the firstline investigation in the clinical evaluation of male breast lumps.

\section{REFERENCES}

[1] Rosen DG, Laucirica R, Verstovsek G. Fine needle aspiration of male breast lesions. Acta Cytol 2009;53(4):369-74.

[2] Silverman JF, Lannin DR, O'Brien K, et al. The triage role of fine needle aspiration biopsy of palpable breast masses- diagnostic accuracy and cost effectiveness. Acta Cytol 1987;31(6):731-6.

[3] Palombini L, Fulciniti F, Vetrani A, et al. Fine-needle aspiration biopsies of breast masses. A critical analysis of 1956 cases in 8 years (1979-1984). Cancer 1988;61(11):2273-7.

[4] Joshi A, Kapila K, Verma K. Fine needle aspiration cytology in the management of male breast masses. Acta Cytologica 1999;43:334-8.

[5] Hammond S, Keyhani-Rofhagha S, O'Toole RV. Statistical analysis of fine needle aspiration cytology of the breast: a review of 678 cases plus 4265 cases from the literature. Acta Cytol 1987;31(3):276-80.

[6] Lilleng R, Paksoy N, Vural G, et al. Assessment of fine needle aspiration cytology and histopathology for diagnosing male breast masses. Acta Cytol 1995;39(5):877-81.

[7] Feichter GE, Haberthur F, Gobat S, et al. Breast cytology. Statistical analysis and cytohistologic correlations. Acta Cytol 1997;41(2):327-32.

[8] Das DK, Junaid TA, Mathews SB, et al. Fine needle aspiration cytology diagnosis of male breast lesions. A study of 185 cases. Acta Cytol 1995;39(5):870-6.

[9] Martin-Bates E, Krausz T, Phillips I. Evaluation of fine needle aspiration of the male breast for the diagnosis of gynaecomastia. Cytopathol 1990;1(2):79-85.

[10] Pailoor K, Fernandes H, Jayaprakash CS, et al. Fine needle aspiration cytology of male breast lesions-a retrospective study over a six year period. J Clin Diagn Res 2014;8(10):FC13-5.

[11] Jatav J, Gaur R, Pandit V, et al. Cytological evaluation of male breast lesions in greater Gwalior: a five year retrospective study. Journal of Evidence based Medicine and Healthcare 2015;2(10):1359-64.

[12] Russin VL, Lachowicz C, Kline TS. Male breast lesions: gynecomastia and its distinction from carcinoma by aspiration biopsy cytology. Diagn Cytopathol 1989;5(3):243-7.

[13] Heller KS, Rosen PP, Schottenfeld D, et al. Male breast cancer: a clinicopathologic study of 97 cases. Ann Surg 1978;188(1):60-5.

[14] MacIntosh RF, Merrimen JL, Barnes PJ. Application of the probabilistic approach to reporting breast fine needle aspiration in males. Acta Cytol 2008;52(5):530-4.

[15] Wilson JD, Aiman J, MacDonald PC. The pathogenesis of gynecomastia. Adv Intern Med 1980;25:1-32. 
[16] Ersek RA, Schaeferle M, Beckham P. Gynecomastia. Aesthet Surg J 2000;5:381-6.

[17] Wauters CA, Kooistra BW, Heijden IMK, et al. Is cytology useful in the diagnostic workup of male breast lesions? A retrospective study over a 16-year period and review of the recent literature. Acta Cytol 2010;54(3):259-64.
[18] Westenend PJ, Jobse C. Evaluation of fine-needle aspiration cytology of breast masses in males. Cancer 2002;96(2):101-4.

[19] Siddiqui MT, Zakowski MF, Ashfaq R, et al. Breast masses in males: multi-institutional experience on fine-needle aspiration. Diagn Cytopathol 2002;26(2):87-91. 